\title{
FAKTOR-FAKTOR YANG MEMPENGARUHI KESELAMATAN DAN KESEHATAN KERJA PERAWAT DI RUMAH SAKIT
}

\author{
Helena Gultom
}

\author{
Email : helenaagultom@gmail.com
}

\section{Latar Belakang}

Rumah sakit merupakan sarana pelayanan yang bergerak dibidang pelayanan jasa kesehatan yang mempunyai beragam persoalan tenaga kerja yang rumit dengan berbagai risiko terkena penyakit akibat kerja bahkan kecelakaan akibat kerja sesuai jenis pekerjaannya sehingga berkewajiban menerapkan upaya pembinaan Keselamatan dan Kesehatan Kerja Rumah Sakit (K3RS). Upaya ini dijalankan agar terhidar dari adanya risiko kecelakaan kerja (Astono, 2010).Kecelakaan kerja merupakan kejadian yang tidak terjadi secara kebetulan, melainkan ada sebabnya. Oleh karena adanya penyebabnya, sebab kecelakaan harus diteliti dan ditemukan, agar untuk selanjutnya dengan tindakan korektif yang ditujukan kepada penyebab itu serta dengan upaya preventif lebih lanjut kecelakaan dapat dicegah dan kecelakaan serupa tidak berulang kembali (Suma'mur, 2013). Keselamatan dan Kesehatan Kerja Kecelakaan kerja disebabkan oleh beberapa faktor menurut anizar (2009) secara umum penyebab kecelakaan ada dua,yaitu unsafe action dapat disebabkan oleh berbagai hal berikut, ketidakseimbangan fisik tenaga kerja, seperti: posisi tubuh yang menyebabkan mudah lelah, cacat fisik, cacat sementara, kepekaan panca indra terhadap sesuatu. Kurang pendidikan, kurang pengalaman, salah pengertian terhadap suatu perintah, kurang terampil, salah mengartikan sop (standard operasional procedur) sehingga mengakibatkan kesalahan pemakaian alat kerja atau penggunaan alat itu sendiri. Keselamatan dan kesehatan kerja merupakan hal yang penting bagi perusahaan, karena dampak kecelakaan dan penyakit kerja tidak hanya merugikan karyawan, tetapi juga perusahaan baik secara langsung maupun tidak langsung (Kusuma, 2001). Sasaran utama dari K3 ditujukan terhadap perawat, dengan melakukan segala daya upaya berupa pencegahan, pemeliharaan dan peningkatan kesehatan tenaga kerja, agar terhindar dari risiko buruk di dalam melakukan pekerjaan.

\section{Metode}

Metode yang digunakan dalam penulisan kajian ini adalah metode literatur review dengan menggunakan buku,ebook ,e-jurnal (10 tahun terakhir ) dan mengikuti format tugas . 


\section{Hasil}

Berdasarkan hasil analisis terhadap beberapa sumber jurnal yang sesuai dengan meteri penugasan di peroleh bahwa faktor -faktor yang mempengaruhi keselamatan dan kesehatan kerja perawat di rumah sakit terdiri adalah ketidakseimbangan fisik tenaga kerja, seperti: posisi tubuh yang menyebabkan mudah lelah, cacat fisik, cacat sementara, kepekaan panca indra terhadap sesuatu. Kurang pendidikan, kurang pengalaman, salah pengertian terhadap suatu perintah, kurang terampil, salah mengartikan sop (standard operasional procedur) sehingga mengakibatkan kesalahan pemakaian alat kerja atau penggunaan alat itu sendiri .

\section{Pembahasan}

Penelitian yang dilakukan oleh Natasia, Loekqijana, dan Kurniawati (2014) mengenai faktor yang mempengaruhi kepatuhan pelaksanaan SOP asuhan keperawatan di ICU-ICCU RSUD Gambiran Kota Kediri menyebutkan bahwa faktor motivasi dan persepsi dapat mempengaruhi kepatuhan perawat dalam pelaksanaan asuhan keperawatan yang sesuai dengan SOP. Perawat dengan persepsi baik memiliki kemungkinan lebih besar untuk patuh dibandingkan dengan perawat dengan persepsi kurang.Selain persepsi, sikap juga mempengaruhi perilaku perawat ditinjau dari segi faktor internal (Notoadmodjo, 2010).

Seorang perawat dalam melaksanakan manajemen K3 harus memiliki sikap yang sesuai dengan nilai-nilai kesehatan dimana seluruh nilai positif yang ada dalam dirinya menjadi pendorong perilaku sehat dan menjadi upaya dalam meningkatkan kesehatan dan keselamatan selama bekerja.Selain itu, Notoadmodjo (2010)menambahkan bahwa ada berbagai cara yang dapat dilakukan untuk meningkatkan persepsi, pengetahuan dan sikap perawat dalam menjaga kesehatan dan keselamatan selama bekerja, diantaranya dengan memberikan promosi kesehatan dan pelatihan tentang K3sehingga hal ini diharapkan mampu merubah perilaku perawat menjadi lebih baik.Selain faktor internal, faktor eksternal juga sangat mempengaruhi perilaku perawat dalam penerapan manajemen K3 di rumah sakit. Peneliti berasumsi bahwa ada banyak faktor yang dapat menentukan perubahan perilaku perawat dari segi faktor eksternal, diantaranya pengalaman. Pengalaman perawat dapat dilihat dari berbagai aspek. Salah satunya adalah masa kerja. Semakin lama masa kerja perawat maka pengalaman yang dimiliki juga semakin meningkat sehingga perilakunya dalam menjaga keselamatan dirinya juga menjadi lebih baik. Selain itu pengalaman juga dapat diperoleh dari berbagai sosialisasi maupun pelatihan tentang K3 yang dilakukan oleh pihak rumah sakit.

Faktor selanjutnya yang ikut berperan dalam perubahan perilaku perawat yaitu tersedianya fasilitas yang mendukung sesuai dengan standar yang telah ditentukan. Hal ini sejalan dengan penelitian Tukatman, Sulistiawati, Purwaningsih dan Nursalam (2015) yang menyebutkan bahwa faktor enabling (fasilitas keamanan dan keselamatan, hukum/aturan) pada perawat berpengaruh 
terhadap K3 pada perawat dalam penanganan pasien. Nilai yang paling tinggi pada faktor enabling berada pada komponen hukum/aturan, artinya secara umum perilakuseseorang dipengaruhi oleh aturan yang ada di lingkungannya.Selain beberapa faktor diatas, budaya organisasi juga berpengaruh terhadap perilaku perawat dalam melaksanakan keselamatan, dimana budaya organisasi yang baik akan mendorong perawat untuk bekerja sesuai dengan prosedur yang telah ditetentukan(Notoadmodjo, 2010). Hal ini sejalan dengan penelitian Mulyatiningsih (2013) tentang determinan perilaku perawat dalam melaksanakan keselamatan pasien yang menunjukkan adanya hubungan yang signifikan antara budaya organisasi dengan perilaku perawat dalam menjaga keselamatan.

Budaya organisasi yang baik mempunyai peluang 2,652 kali lebih besar untuk mempunyai perilaku yang lebih baik dalam meningkatkan keselamatan selama bekerja.

\section{Hubungan antara Sikap dengan Kejadian Kecelakaan Kerja}

Menurut Honda dkk (2014) dalam penelitian di Thailand, terdapat hubungan yang signifikan antara sikap perawat terhadap pencegahan cidera/ kecelakaan akibat benda tajam dan terjadinya cidera akibat benda tajam. Perawat yang memiliki sikap negative terhadap pencegahan cidera benda tajam hampir dua kali cenderung terkena cidera benda tajam dibandingkan dengan yang bersikap positif. Rumah sakit dapat mengurangi jumlah kejadian tertusuk benda tajam dengan meningkatkan sikap perawat dimana sikap sangat berhubungan dengan perilaku. Penelitian ini sesuai juga dengan penelitian yang dilakukan oleh Salawati (2009) dan Sandewa (2014) bahwa sikap ada hubungan dengan kejadian kecelakaan kerja. Direkomendasikan kepada perawat untuk bersikap positif terhadap prosedur pelaksanaan keselamatan dan kesehatan kerja dalam bentuk mendukung/ menyetujui segala program K3 khususnya untuk pencegahan kecelakaan kerja maka diusahakan adanya sikap yang pro aktif untuk mengaplikasikan ilmu baru tentang pelaksanaan keselamatan dan kesehatan kerja. Semakin pro aktif mengaplikasikan ilmu baru maka akan semakin bersikap positif tentang pelaksanaan K3 sehingga akan mengurangi kejadian kecelakaan kerja.Atas dasar rekomendasi diatas maka perlu adanya peran serta Rumah Sakit khususnya bagian Komite K3RS untuk memberikan informasi dan ketetapan standar operasional prosedur yang sesuai dengan pelaksanaan K3 secara bertahap dan menyeluruh.

\section{Hubungan antara Pelatihan dengan Kejadian Kecelakaan Kerja}

Pelatihan keselamatan dan kesehatan kerja merupakan pelatihan yang diselenggarakan dan diarahkan untuk membekali, meningkatkan, dan mengembangkan kemampuan, produktivitas, dan kesejahteraan tenaga kerja. Kebutuhan pelatihan keselamatan dan kesehatan kerja di Rumah Sakit satu dengan Rumah Sakit lain berbeda sesuai sifat bahaya, skala kegiatan dan kondisi petugas kesehatan (Ramli, 2010). Pelatihan keselamatan dan kesehatan kerja sangat penting mengingat kebanyakan kecelakaan terjadi pada pekerja yang belum terbiasa bekerja secara selamat. Penyebabnya adalah ketidaktahuan tentang bahaya atau cara mencegahnya meskipun 
tahu tentang adanya suatu resiko. Direkomendasikan kepada perawat untuk mengikuti pelatihan dan mengaplikasikan ilmu yang didapat dalam melaksanakan tugas yang mengacu pada prosedur K3 terutama untuk pencegahan kejadian kecelakaan kerja.Atas rekomendasi tersebut perlu dilaksanakan pelatihan K3 oleh komite K3RS yang lengkap dan secara berkala bagi seluruh perawat agar memiliki pengetahuan dan keterampilan dalam pelaksanaan tugas sesuai prosedur. Perlu dilaksanakan pelatihan K3RS secara berkala, komprehensif dan merata pada seluruh perawat yang bertugas di Rumah Sakit.

\section{Hubungan antara Promosi Keselamatan dan Kesehatan Kerja dengan Kejadian Kecelakaan Kerja}

Direkomendasikan supaya perawat dapat mencegah terjadinya kecelakaan kerja maka diupayakan media sosialisasi untuk memberikan promosi K3 yang mudah diakses seluruh perawat sehingga promosi K3 dapat terlaksana dengan baik. Atas dasar rekomendasi diatas maka perlu adanya pemanfaatan media sosialisasi oleh bagian Komite K3RS yang berisi tentang prosedur K3 terutama untuk pencegahan kejadian kecelakaan kerja. Untuk itu maka diperlukan media sosialisasi seperti whatsapp yang dapat di akses dengan mudah oleh perawat tentang informasi pelaksanaan K3, sehingga efisien dan efektif dalam menyampaikan promosi K3. Media sosial tersebut dapat mengakomodir kebutuhan informasi, ilmu baru, praktik terbaik tentang penanggulangan kecelakaan kerja yang dikelola oleh Komite K3RS.

\section{Kesimpulan}

Keselamatan dan kesehatan kerja merupakan hal yang penting bagi perusahaan, karena dampak kecelakaan dan penyakit kerja tidak hanya merugikan karyawan, tetapi juga perusahaan baik secara langsung maupun tidak langsung (Kusuma, 2001). Perawat yang sudah memiliki pengalaman dan pengetahuan yang baik tentang penerapan K3, fasilitas yang disediakan serta budaya organisasi yang ada di rumah sakit sudah mengacu pada standar yang telah ditentukan sesuai dengan peraturan KEPMENKES RI 2010 dan peran dari rumah sakit khususnya kepala ruang juga sudah berfungsi secara optimal dalam melakukan monitoring dan evaluasi terhadap kinerja perawat dalam menerapkan budaya Kesehatan dan Keselamatan Kerja (K3). 


\section{Daftar Pustaka}

Putri Sentya.dkk.2018.Pelaksanaan Keselamatan Dan Kesehatan Kerja Terhadap Kejadian Kecelakaan Kerja Perawat Rumah Sakit .Jurnal Endurance.

Nazirah Riska.dkk.2017.Perilaku Perawat Dalam Penerapan Manajemen Kesehatan Dan Keselamatan Kerja (K3) Di Aceh .Idea Nursing Journal .

Nurhidayanti Deni .2017.Pengaruh Pelaksanaan Kesehatan (K3) Terhadap Kepuasaan Kerja Perawat .

Simamora, R. H. (2019). Documentation of Patient Identification into the Electronic System to Improve the Quality of Nursing Services. Jilid 1. International Journal Of Scientific \& Technology Research, Vol.8, No.9,1884-1886.

Simamora, R. H. (2019, September 8). Pengaruh Penyuluhan Identifikasi Pasien dengan Menggunakan Media Audiovisual terhadap Pengetahuan Pasien rawat Inap. Jilid 3. Jurnal Keperawatan Silampari.

Harianto, Joanggi Wiriatarina; , Nursalam; Dewi, Yulis Setiya;. (2015). Keselamatan Pasien Berbasis Knowledge Management SECI Sebagai Peningkatan Kompetensi Mahasiswa Keperawatan. Jurnal Ners .

Iskandar, Edy. (2017). Tata Kelola dan Kepatuhan Penerapan standar Patient Safety Penyakit stroke di Rumah Sakit Dr. Kanujoso Djatiwibowo Tahun 2015. Jurnal Administrasi Rumah Sakit .

Kamil, Hajjul. PATIENT SAFETY. Idea Nursing Journal .

Firawati; Pabuty, Aumas; Putra, Abdi Setia;. (2012). Perlaksanaan Program Keselamatan Pasien di RSUD Solok. Jurnal Kesehatan Masyarakat .

Hakim, Lukman; Pudjirahardjo, Widodo J.;. (2014). Optimalisasi Proses Koordinasi Program Keselamatan (Patient Safety) di Rumah Ssakit X Surabaya. Jurnal Administrasi Kesehatan Indonesia . 